\title{
IV. A Hidden Philosophy
}

Linnæus' youth coincided with an important period of cultural transition. His scientific development firmly points forward. His greatness as a naturalist is beyond dispute. His scientific attitude was shaped by the born naturalist's need to advance by experience. All the same Linnæus is fully aware of the limitations of his experience and the inadequacies of its resources.

Linnæus feels a need to find Nature revealed in a system where experience and reason are to be balanced in an equilibrium. One of his fundamental ideas is that Nature and Revelation can never come into conflict; that they can be reconciled in a unity in which the individual also becomes a part. An ultimate synthesis was for Linnæus an inevitable, even a metaphysical need, which abandons the insufficiency of the immanent outlook on nature, and at the same time represents its mystery.

We know that in his early youth Linnæus came into contact with that ancient science where knowledge very often was magic and magic was knowledge. Linnæus' first confrontation with nature thus took place under such conditions; the details may remain uncertain, but there can be no doubt about such an influence. ${ }^{1}$

At the very beginning of his scientific career Linnæus writes in the unfinished study Fundamenta botanica (1730) that he "cast off all prejudices, became a scepticus and doubted everything". Although it may be difficult to tell exactly what Linnæus meant by this, and although the words perhaps only represent commonplaces of the contemporary debate, the phrase certainly indicates Linnæus' emancipation from his early reading.

1 Here early influences from Johann Arndt, Vom wahren Christenthume (Swedish transl. in 1647) have been suggested by Hilding Pleijel, The Devotional Literature of the Swedish People in Earlier Times, Opuscula Instituti Hist.-Eccl. Lundensis 4, I955, pp. 20 sq. There are elements of Paracelsic Hermetism (Sten Lindroth, Paracelsismen $i$ Sverige, Uppsala I943, pp. 43 I sqq.). It is, however, difficult directly to identify Linnæus' outlook with Johann Arndt's. 


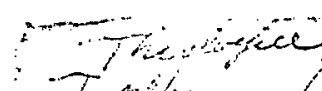

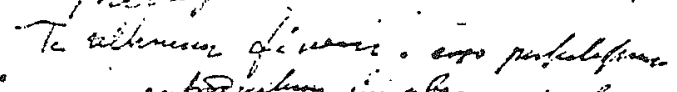

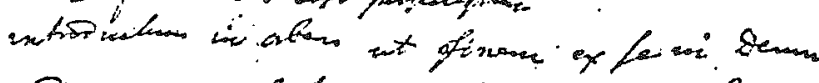

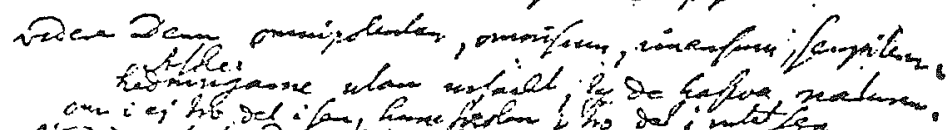

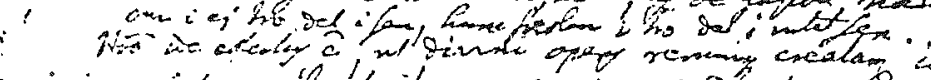

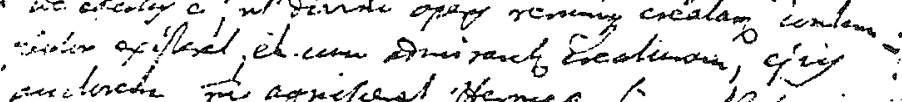

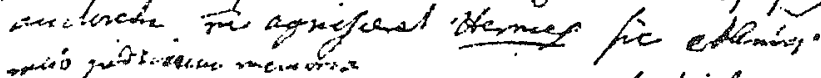

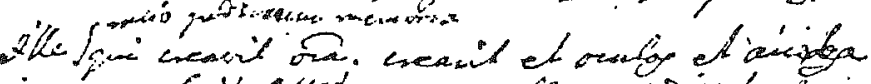

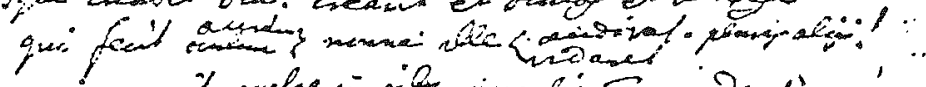

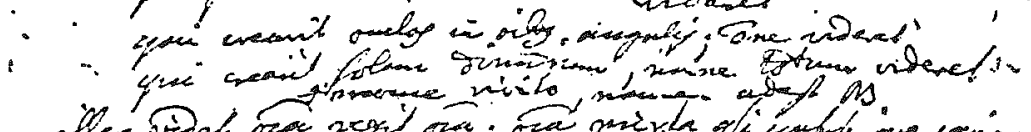

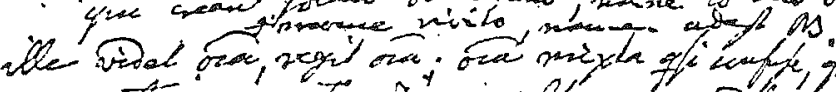

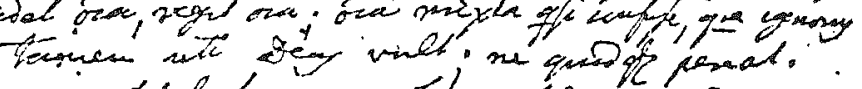

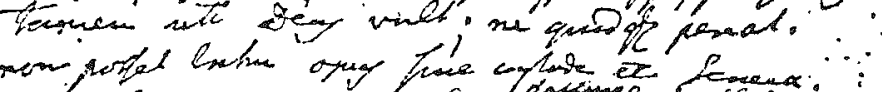

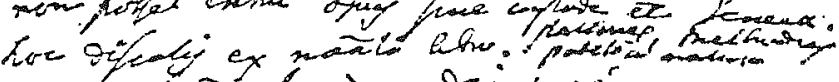

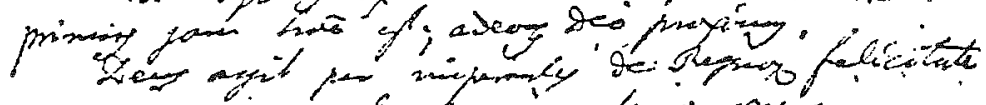

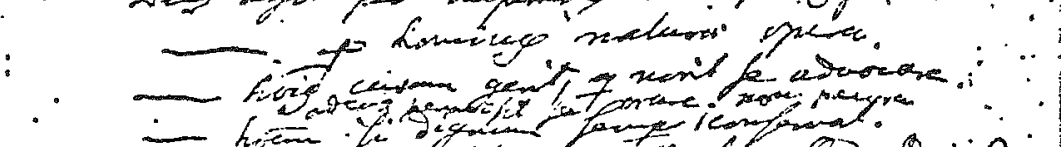

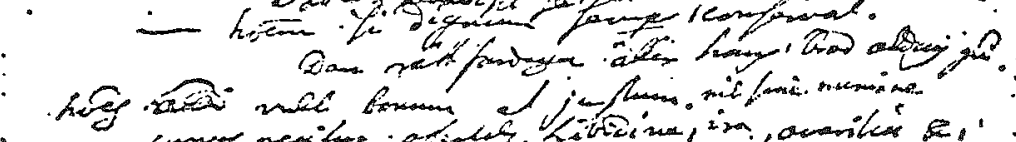

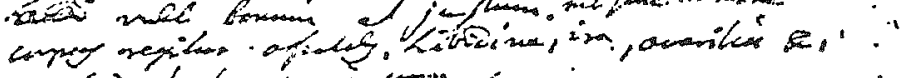

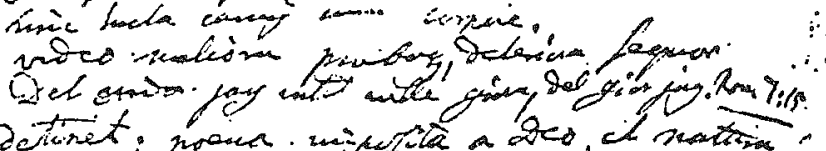

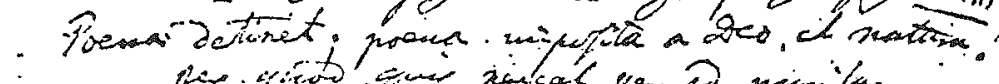

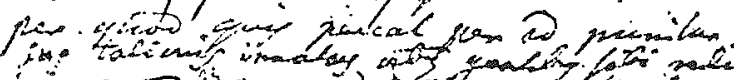

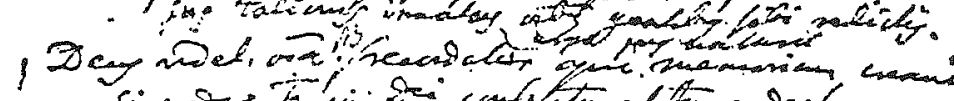

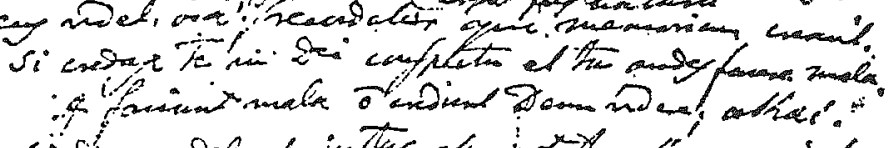

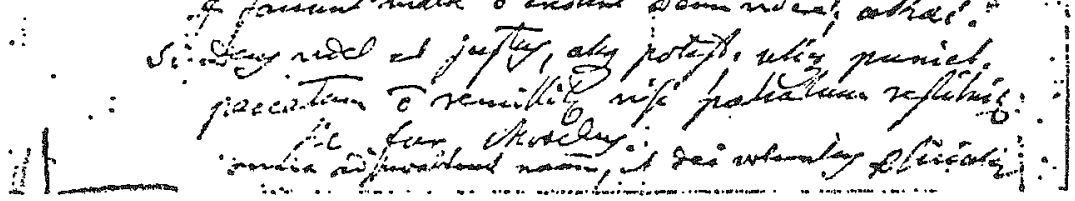

Facsimile Theologice. 
In the latter part of Dixta the young Linnæus confesses his religion of Nature. ${ }^{1}$

Deum existere probant sensus omnes externi, quocumque vertuntur, adeo ut si ad sidera coli, solem et lunam, totque myriades stellarum tanto spatio remotarum, oculos meos converto, certas servare stases, jam accedere, jam recedere, cum terram considero, tantæ molis mente describo. - - -

Cumque considero structuram proximarum rerum, qvumque oculos converto, non ex nihilo profluxisse ea omnia miranda, quæ homini licet essent cognita, a nullo artifice produci, multo minus casu, nonne tum creatoris sapientiam agnoscam. A motu et ordine perpetuo siderum nonne conservatorem videam, a multiplicatione animalium et plantarum retro numeratorum ad unitatem, nonne creationem videam. - - -

Nullum punctum adest visibile quod non in structura vero theologo est indescriptibile. - - -

Ingen är svårare än theologi att propugnera de gambles theorie om generationem æqvivocam insectorum minimorum, quibus dicendum est, quod si hæc animalia æquivoce generari probari possunt, ego
That God exists prove all outer senses, whatever they are directed at, as well as if I turn my eyes to the stars of heaven, the sun and moon and so many myriads of stars so remote, and I try to keep them in their conjunctions when they sometimes draw near and sometimes disappear, when I consider the earth, and describe them with so much mental pain.

And when I take into account the things close to Nature and turn my gaze towards all these wonderful things which man has been permitted to learn, I should admit that they were not brought forth by an artist and even less by chance, should I then not admit the wisdom of the Creator. Should I not from the perpetual movement and order of the stars see the Conservator and from the reproduction of animals and plants, when they are referred back to the unity, see the Creation.

There is no mote which we can discern and which a true theologian cannot describe in its structure.

Nobody is worse than theologians who strive for the theory of the ancients about generatio æquivoca of the smallest insects, to them has to be said that if they can prove that these animals produce

1 DN pp. I9I sq. Three dashes indicate some clauses left out by the author. Cf. the Swedish translation by E. Malmeström, op. cit., p. 327, which, totally omits the last paragraph. The next heading runs as follows: "Theology is curiously varying" $D N$ pp. 192 sq.; cf. above p. 29. Already in his avis au lecteur in $D N$, p. 19, Linnæus deprecates ideas of generation without a father. 
eqvum et vaccam similiter et facilius probabo, cur non ipsum hominem.

O, talpæ magis coci! zquivoce, I shall in some way prove more easily that horses and cows and, why not also man, produce in the same way. $\mathrm{Oh}$, they are blinder than moles!

The wording bears a certain resemblance to a cosmic hymn to God and his wonders in nature, the stars and the wandering planets and looks more like the famous prisca theologia than ever any Christian confession. Linnæus' claim to be a "true theologian" and his harsh diatribe against the believers in virginal generation hardly hide such an attitude.

At any rate such impressions seem to have survived in Linnæus' mind. The undercurrent is rarely quite clear, and in many cases the meaning becomes elusive and the arguments ambiguous. This mode of thought was a handicap of the eighteenth century and was inherited from a period when symbols and allegories were claimed to convey truths.

It is this background which may be called the hidden philosophy of Linnæus. The reasons for Linnæus' visions of the world are ultimately to be found in his own heart. It was a question of conflicting ideas both in Linnæus' personality and in his environment.

In Lachesis naturalis Linnæus' ideas appear only in fragments, as memoranda. This reservation has to be kept in mind when we approach Linnæus' often concealed trains of thought. Perhaps most elucidating on this theme are two leaves of the unpublished Lachesis manuscript. The passages which are rendered below appear under the heading Theologice. The dating of these pages may be uncertain; most likely they orignate from the beginning of $1760 s .^{1}$

Te ultimum finem ergo perfectissinum introductum in orbem ut finem ex se in Deum.

Videre Deum omnipotentem omniscium, immensum, sempiternum.

Athei.
Regard yourself as the ultimate end, and therefore as the most perfect (creature) brought into the world as an end in itself unto God.

To see God as the almighty, allknowing, immense and eternal.

The deniers of God.

1 A passage overleaf seems to refer to the Pommerian war of Sweden and is probably written in the year 1762 . O. E. Hjelt, op. cit. p. 45 and note. 
Homo ideo effectus est, ut divini operis rerum creatarum contemplator existeret, et cum admiraretur creaturam, ejus auctorem etiam agnosceret Hermes sic ethrici ratio judicium memoria. ${ }^{1}$
Man is therefore so contrived that, be he a beholder of the divine work and things created, when admiring the creation, he should also recognize its originator. This is the opinion of Hermes, the pagans, reason, judgement, and tradition. ${ }^{2}$

The style is rather hymnic and visionary. The last words sum up in an asyndeton the content. No matter how we read these lines they sound like a far echo from Renaissance poetry. In the Asclepius text in Corpus Hermeticum we read:

Contemplate the world, and consider its beauty. See the hierarchy of the seven heavens and their order. See the earth, settled in the midst of the All, the great nurse who nourishes all terrestrial creatures...

And so, $\mathrm{O}$ Asclepius, man is a magnum miraculum, a being worthy of reverence and honour. For he goes into the nature of a God as though he was himself a god. ${ }^{\mathbf{3}}$

Linnæus pays homage to a God who shapes the world to be an object for contemplation and admiration and, on the other hand dignifies a man doing so. But that is not all. In what follows Linnæus designates man as the first and nearest God (adeoque Deo proximus) and declares that God preserves a man worthy of Him (si dignum conservat). The Dignity of Man was a gospel of Renaissance Hermetism which heralded the Declaration of Human Rights. As seen from his Nemesis Linnæus was not quite unaware of such ideas in his own time. Nor was he unfamiliar with the thought that he him-

1 The text closely follows Linnæus' lecture at the Degree Ceremony in Upsala in I763: Oratio de fine Creatoris ex opere naturæ, publ. by Arvid Hj. Uggla, $S L S A$ XXX, 1947; the original text p. 89: Sic omnia creata facta sunt in Gloriam Dei, per hominem, qui caput est systematis naturæ. Factum sic esse creationis magnificentissimum opus, in gloriam sui creatoris, dictitat ipsa ratio; assentiunt omnes sapientes, immo ipsi gentiles; athei ideo excusatione carent. The last sentence explains the isolated word athei above.

2 The original text according to Malmeström who in several places has introduced an interpretation of his own. SLSA XXII, I939, pp. 6o sq. Cf. pp. 68 sqq. The MS renders a hint of the Rabbinical legend: Moses in Sinai Arabibus, which Linnæus refers to ( $N D$-MS 27). See above p. 86.

${ }_{3}$ Corpus Hermeticum, ed. by A. D. Nock and A.-J. Festugière, Paris I945-I954, II, pp. 30r sq. English translation from Frances A. Yates, Giordano Bruno, London I 964 , p. II I, cf. pp. 35 sq. 
self in some way was one chosen by God. It seems, however, less likely that he should have observed that $a$ priori this device included a mystic sanction not only for a Magician but also for a Genius. Probably he never read Pico della Mirandola.

In a survey appearing on the same leaves on which he had written down this old Hermetic wisdom, Linnæus begins by treating the Chaldeans, Egyptians and Phonicians as the founders of the science taken over by the Greeks and Romans. But when he comes to the Christian era after the death of Marcus Aurelius, he emphasizes, not only the decline, but also "the unfortunate delusion, which still persists, that the two words of God, Nature and Revelation, are at variance with one another". Nature was regarded either as something exceeding human strength, or as something contemptible. It was only during the fourteenth century that things began to brighten up, and in the sixteenth century science was again being encouraged. From the seventeenth century Linnæus mentions Galilei, the boast of Italy, and also Kepler who followed in the tracks of Tycho Brahe. There is no need to repeat Linnæus' enumeration of names, which at that date was still typical of the conception of the history of science.

It can hardly be denied that phrases and expressions in the passage quoted above are derived from Hermetic sources. This is evident from the very key words Hermes (Trismegistus) and cognito sui of the Lachesis, as well as from the often repeated phrase Nosce te ipsum in Systema naturæ. ${ }^{1}$

Hermes, with whom we are concerned here, is already mentioned by Cicero in De natura deorum as a cultural hero of Ancient Egypt. He had become an eponym for the literary tradition of late Hellenic times called Corpus Hermeticum. ${ }^{2}$ Remnants of it were preserved through the Middle Ages thanks to Apuleius of Medaura and the Christian Fathers, Lactantius and St. Augustine. The main works of this neo-Platonic and Gnostic tradition, Asclepius and Pimander, were edited and commented on by Marsilio Ficino in the last decades of the fifteenth century. From Ficino and the Florentine Platonists there started the mighty stream of Hermetism in the following epoch with its undercurrents of Natural Magic. On this Faustian

${ }^{1} L N$, p. I 56 .

2 The great work by A.-J. Festugière, La révélation d'Hermès Trismegiste (1950-54) gives a comprehensive analysis of the neo-Platonic and Stoic ideas in this tradition. 
104

stage we meet with neo-Platonic thought and magic in the persons of Cornelius Agrippa, Paracelsus and John Dee. "All present much the same picture", says a Cambridge humanist of today, E. M. Butler, "that of men actually generations ahead of their times in learning and science, but real children of their age in following truth down those alluring bypaths which seemed to be royal roads to knowledge and proved to be delusory."'

Hermetism was a product of the syncretic early Medievalism with traits of Hellenic philosophy and Christian Gnostic and Manichean ideas, which within the scope of neo-Platonic thought embraced Christian beliefs at the beginning of the New Era. An important feature of this Platonistic thought was that it was anti-Scholastic, and consequently anti-Aristotelic. This attitude made its representatives take up arms against church and society. But the Inquisition always threatened with prison and the stake. Ideally and ideologically, however, Renaissance Platonistic ideas had an importance which has often been overlooked. Its prescientific superstructure of astrology and alchemy, ritualistic magic and secret social tendencies stood in the way of an evaluation of its external effects and intrinsic worth.

From this point of view the two outstanding figures, Paracelsus and Agrippa, have been too often misunderstood and inadequately treated. A great hindrance to the historical understanding of their intellectual climate has not only been the enormous mass of pseudographs and forgeries and, in addition, all the spurious obscurantism of the 16 th and 17 th centuries, but also the narrowness of the scientific ideas of later times. Much light has however been thrown especially on Agrippa of Nettesheim, during the latest decades through the writings of Will-Erich Peuckert. ${ }^{2}$ The magnificent facsimile reprint of Agrippa's Occulta philosophia, edited by the Austrian scholar Karl Anton Nowotny, throws new light on this famous work and retrieves its author in more than one respect. ${ }^{3}$ An original version from $5_{5}$ IO of this work has also been published and comparisons are made by Nowotny with the Agrippan writing De incertitudine et vanitate scientiarum atque $\operatorname{artium}\left(\mathrm{I} 73^{\circ}\right) \mathrm{.}^{4}$

\footnotetext{
1 E. M. Butler, The Myth of the Magus, Cambridge I948, p. I6I.

2 W.-E. Peuckert, Pansophie, [I] (and ed.)-II, Berlin I956-67.

${ }^{3}$ Henricus Cornelius Agrippa ab Nettesheym, De occulta philosophia. Herausgegeben und erläutert von Karl Anton Nowotny, Graz 1967.

4 Op. cit., p. 417. Idem Opera (Lyon-edition) vol. II.
} 
In order to illustrate the intellectual atmosphere of Occulta philosophia a summary of its ideas may be cited from Nowotny: "The world is a unit with three stages (the intellectual, the celestial and the earthly). The entirety and all its parts are animate. When the first note is struck on one of many equally tuned lutes all the others vibrate; thus are all worlds intervowen by an endless amount of relations. The Evil is the conversion of the Good but at the same time nothing real and it is impossible for man to raise himself to the highest forms of Cosmos or to draw them to himself."' More than any Platonic philosophy this sentiment tarried for a long time in the cultural consciousness of our western part of the world.

A very outstanding example in Sweden of the surviving ideas of earlier date is the small book by Count Gustaf Bonde Clavicula Hermeticæ Scientiæ, on the title-page of which it is stated to have been written in $1732 .^{2}$ The booklet was published anonymously in Marburg in 1746 and reprinted, with a parallel French text, in Amsterdam in 175I. Its author and its contents must have been known to Linnæus. Count Bonde was honorary president of the Academy of Sciences in Upsala, member of the Academy of Sciences in Stockholm, Chancellor of the University of Upsala 1 737-1739, and author of a large number of historical, political and economical papers. Bonde had presumably developed the hermetical way of thinking at the beginning of the eighteenth century during his years of study at Tübingen. This was also where Valentine Andreæ had created the Rosicrucian legend at the start of the previous century. Clavicula is not a particularly important paper, and the contents may be described as Christian hermetical nature mysticism. It is dedicated to Deo trino et uni, Naturæ Virgini impollutæ et

1 Op. cit., pp. 404 sq. (Translated from the German.)

2 The complete title is Clavicula Hermeticæ scientiæa ab Hyperboreo quodam horis subsecivis calamo consignat(a). Marburg I746. In the Amsterdam edition a number of corrections have been inserted with a French translation, printed in the year 175 $\mathrm{I}$. Here the copy belonging to the University Library of Upsala has been used, in a xerographic copy put at my disposal. In a somewhat altered form the Clavicula was translated into Swedish by C. B. Trozelius, professor of economics in Lund, and published in a series of academic dissertations during the years $176 \mathrm{r}-177 \mathrm{r}$. Count Gustaf Bonde (1682-1764), studied for J. Creiling in Tübingen in 1702-1703, (see Svenskt biografiskt lexikon V, about his hermetical speculations pp. 373 sq.). Creiling later published books where he defended alchemy. 
Arti, and it starts with a confession of man's inner knowledge and of the harmony between man and his outer world. Here follows a well known quotation from Corpus Hermeticum:

For this reason man is, $\mathrm{O}$ Asclepius, a great wonder, a creature worthy of honour and admiration. ${ }^{1}$

According to the vocabulary of Corpus Hermeticum Nature is an "innocent virgin". The xóp xóøuou of Stobæus is the Isis symbol of the gentile tradition and brings to mind the dream which Valentine Andreæ had of the alchemical "wedding". 2

It may be left unsaid of what use the hermetism of Count Bonde might have been for Linnæus. Strangely enough, however, we find that the vocabulary of hermetism frequently occurs in Linnæus' writings and orations in subsequent years. As far as I can see, this tendency is found in the famous passage on the journey to Western Sweden, when Linnæus passes the churchyard of Frändefors in Dalsland. ${ }^{3} \mathrm{I}$ am not prepared to give a conclusive interpretation of this passage, which, more or less aptly, has been called "the Hamlet monologue" of Linnæus. (By the way, the passage seems to be mere desk-work, elaborated for the printing press after the journey.) Here Linnæus meditates in words not very unlike those of the Ecclesiastes of the Old Testament on Life and Death in the curriculum of Nature. One cannot err about the high tension of his expressions. The problem behind it is the eternal question about life's cause and meaning. It was Linnæus' perpetual companion during his years of bad health, infirmity and distrust in his late 4 os. But even here Linnæus has the very conspicuous tendency to express himself about intriguing topics in a seemingly contradictory manner. Thus when Linnæus confronts lapis philosophorum, philosophi Pythagoræi, metempsychosis and Gymnosophistæ in his journal in a rather controversial form, the hermetic keywords signify an ambiguous note in himself. Also

${ }^{1}$ Consule te ipsum, nosce temet/Et ambula ab intra. Quod est superior est sicut id, quod est inferior. Propter hoc, o Asclepi, magnum miraculum est homo, animal admirandum et honorandum. Op. cit., pp. 5 sq.

${ }^{2}$ Chymische Hochzeit, Strassburg I616. In the second edition of Clavicula the Trinity is omitted.

${ }^{3}$ Carl Linnæi Wästgöta-resa, förrättad $r 746$, Göteborg 1747, pp. 225 sq. The preface is dated April 8, I747. The book is dedicated to the Crown Princess, later Queen of Sweden, Louise Ulrica, a sister of Frederick the Great of Prussia. 
when, in my opinion somewhat obscurely, he suggests that matter contains the potentialities of the offspring. ${ }^{1}$ Presumably the following lines from Clavicula about the Prime matter reveal similar views on the part of Linnæus. "Materia mea nec est animalis, nec vegetabilis, nec Mineralis, sed ex omnibus participans, universalis et plus quam ulla alia in mundo res, per sympathiam Microcosmica nominari potest et meretur, semper et ubique... Numquam in quiete, semper in actu et motu. Numquam in propatulo, semper in occulto... Agnoscit originem suam e terra, e colo vitam... Unde animata non mortua."2 Irrespective of where Linnæus culled his hermetic vocabulary, I think we cannot totally exclude some influences from the same quarter as that of the anonymous author of Clavicula.

It is also noticeable that in his academic orations during the subsequent years Linnæus uses hermetical terms paraphrased in his own words. This tendency has been observed by Dr. Ingrid Odelstierna of Upsala, who has translated and commented upon Linnæus' orations as Rector of the University of Upsala. ${ }^{3}$ She calls attention to a couple of learned phrases in the orations. Most interesting are two orations delivered in the early 1750 os on important dates in the lives of the Crown Prince Adolf Frederick and his richly endowed consort, Louise Ulrica, whose praises Linnæus could not sing loud enough. It is rather uncertain to what extent these orations were written down by Linnæus. As he himself said, he never was "a Ciceronian nightingale". The style reflects little of his own manner; sometimes it seems too ambiguous or rather too disguised. Nevertheless Linnæus certainly stood for the contents. In an oratorical manner of speaking he touches upon public affairs in terms of microcosm and macrocosm and their mutual reports. The words are repeatedly phrased in the formula quod est inferius est sicut superius and conversely. It is a sentence from the renowned Emerald Table, which is probably referred to as the "secret writing of the ancients".

1 The Swedish text is very difficult to render. It runs: "då wäxter och djur förmultna, blifwa de til Mylla; Myllan blifwer sedermera til födo för de wäxter, som deruti sått och rotat sig, så at den största Ek och den fulaste Näsla äro af enahanda ting hopsatte, nämligen af de finaste swartmyllans particlar genom Naturen, eller lapis Philosophorum, som Skaparen satt uti hwart frö at förbyta och förwandla Myllan till sin egen art." Op. cit., p. 226.

2 Op. cit., p. II; in second ed. I75I, pp. 36-39.

${ }^{3}$ Rektorsprogram, edited by Ingrid Odelstierna, Valda avhandlingar av Carl von Linné no. 4I, Ekenäs $196_{3}$, see nris I and III with the comments by the editor. 
The eighth sentence of the famous table runs: Ascendit a terra in cælum, iterumque descendit in terram, et recipit vim superiorum et inferiorum. Sic habetis gloriam totius mundi. ${ }^{1}$ Truly, a secret message to a prince, if you like!

In the opening of the oration the cosmic vision of Cicero in the famous Somnium Scipionis is referred to, and this has perhaps also been taken from some hermetic source. ${ }^{2}$ The allusion to Saturn in the same paragraph, which I cannot but find ambiguous, seems to me even more enigmatic than that. It could very well refer to Linnæus, being at that time "a child of Saturn". Despair and jollity were alternating constituents in Linnæus' disposition. Whenever brooding on the religious and philosophical disputes of his time, a melancholic vein appeared during the periods of adversity and bad health. ${ }^{3}$ However, I cannot suppress a suspicion that the cropping up of the occult tendencies had some connection with Rosicrucian and Freemasonic sympathies at Court.

The "Era of Freedom" in I8th century Sweden is manifested through a wave of occult sciences and secret societies. From a sociological point of view the patterns of thought, the sentiments and esoteric myths, legends and rites which became dominating were renewed from the great store of Hermetism and Pansophic wisdom. As Professor W.-E. Peuckert states, this connection is beyond doubt. ${ }^{4}$ The beginnings are to be found in England and France but perhaps still nearer home in influences from the Teutonic countries and, as may be supposed, not least from the circles of the PrussianBrandenburg Court.

When considering the real Linnæus one should notice that his philosophic devotion to Nature was inherently teleological, whereby it was possible for him at times to take purposes for causes and causes for purposes. His primary curiosity about Nature fluctuated between opposites such as naiveté and brooding. His academic writings $D e$ curiositate naturali in 1748 and $D e$

\footnotetext{
1 I quote W.-E. Peuckert, Pansophie, [I], p. 88.

2 Somnium Scipionis, c. IV is cited for instance by Copernicus, see Frances A. Yeates, Giordano Bruno, London 1964, pp. I54 sq.

${ }^{3}$ Elis Malmeström, op. cit., pp. I I4 sqq.

${ }_{4}$ W.-E. Peuckert, Geheim-Kulte, Heidelberg I95 I, pp. 567 sqq., especially pp. 606 sq.
} 
ceconomia naturæ in I749 clearly illustrate this fact, which is interesting as far as they reflect an essential difference between the scientific and the theological learning at the University. Such controversies always left deep marks in the mind of Linnæus. Alternating feelings of self-reliance and piety created tensions which could hardly be solved by anything other than an appeal to the High Court of Nemesis Divina. This was also the result when in his pamphlet Ouvrage de Pénélope in I748, La Mettrie attacked Linnæus. ${ }^{1}$ Obviously the "Experimental theology" of Linnæus could never function without the idea of Divine Retaliation.

But also Albrecht Haller dissociated himself from the extreme materialism of La Mettrie.2 Linnæus had in common with his great master in medicine, Boerhaave, the vital aspect on mind and body. His reasoning becomes striking when we read his notes concerning the diseases of the nerves. I quote a Boerhaavian prelection note from December $\mathbf{~}$ oth, $\mathbf{I} 733$, slightly abbreviated: In morte enim... sensu affectu animi, et motu enormontico, deletis, principio cogita(nte) puro, intelligentia, et voluntate, in causam originalem, DEUM, integre converso, absque ulterior(e) commercio cum corpore actuoso, vel patiente. ${ }^{3}$ The words convey, perhaps a bit roughly, the Boerhaavian view on the crucial Cartesian problem of body and mind-as I think, not very far removed from the sentiments of Linnæus. ${ }^{4}$

The rather bewildering features of the progressive sciences in these centuries are impossible to trace here. Independently of all the great contrasts of thought and faith at the end of the sixteenth and the beginning of the seventeenth centuries Renaissance magic entailed the purpose of pulling down the life of heaven to the alleged sympathetic relations on this earth. The active imagination and intention of Homo Magus represented the aspects

1 Elis Malmeström, op. cit., pp. I I4 sqq.

${ }^{2}$ B. P. M. Schulte, Hermanni Boerhaave Prælectiones de morbis nervorum I730-I735, Leiden 1959 , p. 39x.

3 Op. cit., pp. 270 sq.

4 Concerning Descartes and Boerhaave Schulte says: „I zijn opvatting over the causaliteit van God is Boerhaave I733 als het ware Cartesiaaner dan Descartes. De opvatting van Boerhaave, die hierin bestaat dat, hij de causaliteit van God vergroot om zo de causale betrekking tussen ziel en lichaam teniet te doen, ligt in de lijn van de Occasionalisten" (De la Forge, Geulincx and Malebranche). Op. cit., pp. $3^{85}$ sq. $8-684409$ Wikman 
of macrocosm and microcosm. For a long time Marsilio Ficino's most reputed work was his Libri de vita, the dietetic part of which, De vita tripartita, was familiar to Linnæus. The line of descent in medicine from Ficino through Paracelsus to J. B. van Helmont with Campanella, Fludd, Croll and other adherents of the Hermetic medicine as links, could not be wholly eradicated by the efforts of Gassendi, Marsenne and Descartes in physics. It is worth noting that the gap between Paracelsus and Van Helmont is considerable, for the Vitalism of Van Helmont shows no longer remnants of the micro-macrocosmic symbolism for which Linnæus still had some predilection. ${ }^{1}$ When the legend of the Egyptian Hermes was brought out into the day-light by Casaubon, christianized Hermetism had changed the Homo Magus to the Deus Magus. From Campanella onwards this trend becomes conspicuous.

One consequence of this evolution of thinking was that Hermetism became a utopian ideology, a mighty, but seldom adequately appreciated force in this development. Campanella's Città del Sole (Latin version r624), however, became emblematic for the influence of this esoteric Western Platonism. The earliest germs of this tendency may be found in Plotinus. The social evolution of Pansophism, which here included Rosicrucianism and Freemasonry, were legitimate inheritors of the same spirit. In fact, this background of Bureus and Stiernhielm in Sweden should never be overlooked when speaking of Linnæus.

Still in Linnæus' days and a long time after medicine was surrounded by much of its old philosophical halo. This is obvious not only, as we have seen above, from the way he favoured the general discipline of dietetics but also from his ways of thinking in schemes of medical systematics.

1 Walter Pagel, $\mathscr{7}$. B. van Helmont, Osiris VIII, r948, pp. $35 \circ$ sq. and note 8. Pagel remarks that Van Helmont does not represent a strange Hermeticism but "a serious trend of thought showing the way to genuine science". Op. cit., where other writings by Pagel are cited; cf. W. Leibbrand, op. cit., pp. 273 sqq. 
To Linnæus all Nature was Life, he said that the stones were alive: lapides crescunt. In the annotations to Clavis we come across sayings such as: Nature and Mind are two sisters. "When the Mind is in trouble she calls upon Nature, her sister, and Nature is prudent, wise and the body's friend." "They often agree, but they also sometimes fight each other." "When the source of motion fails, I dwindle away." There is, however, no reason to believe that he meant that Nature and Mind coincide. Growth, life and sense were three rungs on the ladder, a topic certainly not without connection with fundamental neo-Platonic ideas. According to the vitalistic ideas of Linnæus the native powers are the vires of living objects, but he never regards them as being activated by the stars or as being derived from the similarities between the objects of nature. Neither does he find it very credible that the vital force might be analyzed as fire in the organic world. Nor is he an adherent of astrological, alchemical ideas or the theory of signatures. These premises must be strictly kept in mind when Linnæus' Clavis is considered.

The 1750 and 1760 s were filled with outward strivings which extended Linnæus' world-wide knowledge of nature. However, these years were also filled with intervals of profound distress and melancholic self-searchings. Such feelings may have been partly caused by bodily infirmities, and partly by Linnæus' mental constitution. In conformity with this condition, feelings of pronounced self-assertion and high-tensioned ambition were never very far away. It seems impossible to arrive at any other conclusion concerning the origin of the Linnean system of systems, the booklet Clavis medicinx duplex, which was edited in $\mathrm{I} 766$, but had been prepared several years earlier. Even the superlative homage paid to the most prominent contemporaries in medicine and botany, Albinus, von Haller and Van

1 Clavis-MS sub Natura et Mens: Mens in angustiis pollicet Naturam sororem. Natura prudens, sapiens, sibi amica corpori. Utraque sæpe consentiunt, interdum lucta. Amisso molite deliquesco. See above p. 20. 
Swieten, together with Sauvages and von Rosenstein, tells us about an anticipated recognition, which, unfortunately, failed to materialize. In actual fact Clavis is difficult to place in any other context than that of Linnæus' system of Nature in which it plays the part of a medico-botanical appendix. Linnæus called his treatise the "keys to the temple of medicine". ${ }^{1}$ By this he indicated the esoteric character of his work. In fact Clavis opened no doors. It remained a closed book for contemporary as well as later science.

In order to understand Clavis we must return to the young Linnæus and especially to those parts of his background which were formed by Renaissance and Baroque medicine with their classical roots. When Linnæus started his career much speculative medicine survived in the tradition inherited from the preceding period. It was a tradition derived from the numerous tributaries of older and more recent elements. During the scientific evolution, however, this vast current of ideas slowly faded.

According to an age-old principle of philosophical medicine, already explicitly formulated by, among others, Pythagoras and Empedocles, the disturbed equilibrium of Nature could be restored by placing a counterweight on the scale of Nature. ${ }^{2}$ Linnæus' motto on the title-page of Clavis medicina duplex expresses the same idea that the equilibrium of this world can be produced only through the struggle for power fought between opposites: Universum lucta discordium rquilibratur. We should not expect Linnæus to have given the proposition a more profound philosophical justification. In fact it may be interpreted both materially and dialectically, dynamically and structurally. The idea was at the same time an expression of the motive and the foundation for Linnæus' systematization. Paradoxically, this makes his system as untenable as it is intriguing. Here we are faced with the profound conflict between the statical and dynamical aspects of diseases which had pervaded in medicine ever since Paracelsus. The ques-

${ }^{1}$ Letter to Abraham Bäck r/I I866, cited by Hjelt, op. cit., p. I29.

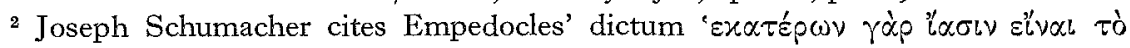
Evavtiov and shows how philosophically a very different content can be put in the conception of harmony. Antike Medicin, 2nd ed., Berlin 1923, p. r2r. "The human body can be considered as equilibrating when we are well, but when weight exceeds on either side, we are sick", Linnæus said according to the college-notes to his prelections concerning Clavis (University Library of Upsala). Otto E. A. Hjelt, op. cit., p. 75, note 4 , cf. p. 235 . 


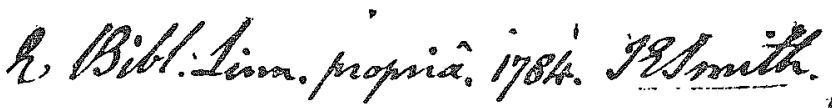
CAROLI A LINNÉ EQU. AUR.

ACAD. REG. PARIS. MEMBR,
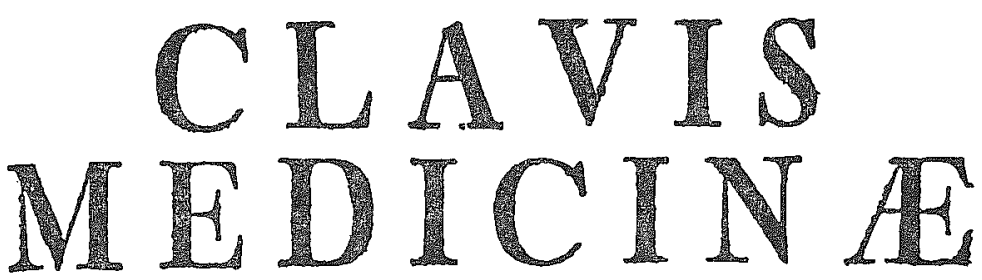

DUPLEX,

EXTERIOR \& INTERIOR.

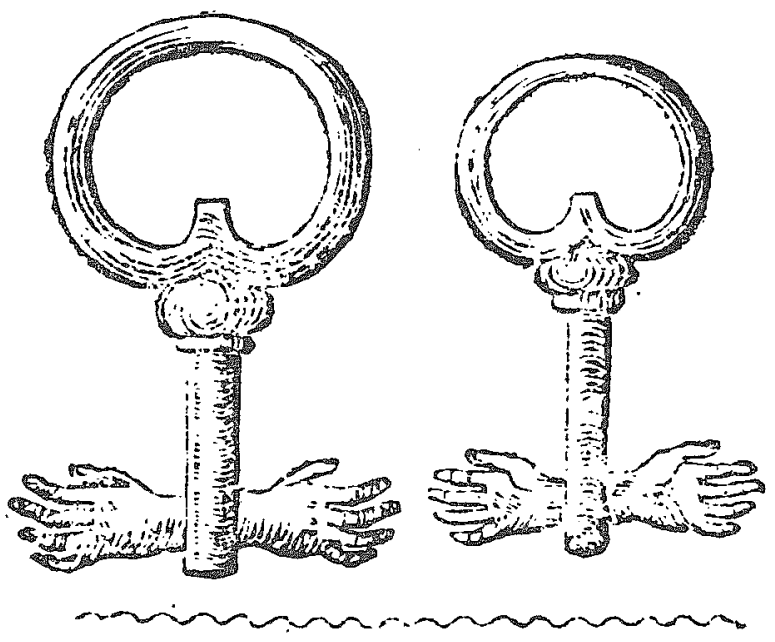

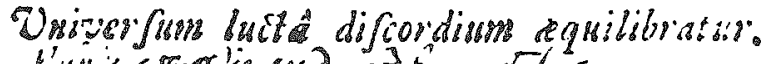

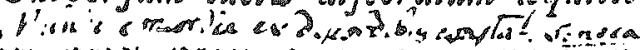

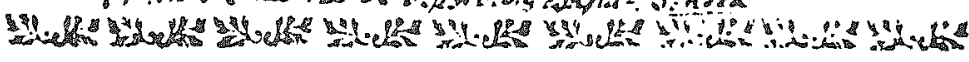

$$
\begin{aligned}
& \text { HOLMIAS, } \\
& \text { IMPSTSD DIRET. LAURENTIISALVII, } \\
& 1766 \text {. }
\end{aligned}
$$


tion can, however, be raised whether or not Linnæus' motto aimed even further. Many times Linnæus looked upon the struggle of life as a war of all against all. The equilibrium then was only a truce under the revenging hand of God.

The scope of Clavis is dichotomic and pentatomic. This principium contrarietatis quinquefarium is openly indicated by Linnæus in the following words: "Nature divides it all; first in two, and then into five."1 The idea of the dichotomy of organic nature, which was of fundamental importance to Linnæus, was principally propounded in a thesis in 1759 , De generatione ambigena. The organisms are comprised of a female medullar and a male cortical substance. This is the case with animals as well as plants. ${ }^{2}$ With this theory Linnæus obviously extended his sexual system with a grandiose, although sweeping analogy, for which there was no firm empirical backing.

In this connection the primal, rather visionary experience of the young Linnæus concerning "the Wedding of the Flowers", should be emphasized. This he enthusiastically announced in humanizing terms such as "Love unites the plants". In his 'Philosophy of Botany' he designates himself as a sexualista and declares that "sex is the beginning of everything". ${ }^{3}$ In accordance with this the organic world became divided into two and therefore the whole system of Nature also became dichotomized.

The essentials of Linnæus' system of Nature were the facts of generation and propagation. These were fundamentals also for the views on organic evolution, held by Darwin and his forerunners and followers. The truth about Linnæus was simply that the mould must be broken, when the castings were brought out. Linnæus was aware of the problem, but he was a prisoner of his own system. In many respects science, at this time, moved in parallel or converging lines as far as causes and purposes were concerned. The bifarious feature of the system-building of Linnæus carried with it much ambivalence and ambiguity, often disguised by a twilight of similarities and symbols which particularly characterize the superstructure of the system.

As a reminiscence of earlier periods the doctrine of the elements reappears in the latest editions of Systema naturæ as well as in the Clavis notes. The

${ }^{1}$ See Otto E. A. Hjelt, op. cit., p. I28. ${ }^{2}$ In details Hjelt, op. cit., pp. 58 sq., I 28.

${ }^{3}$ Philosophia botanica, pp. 13, 24, 86. 


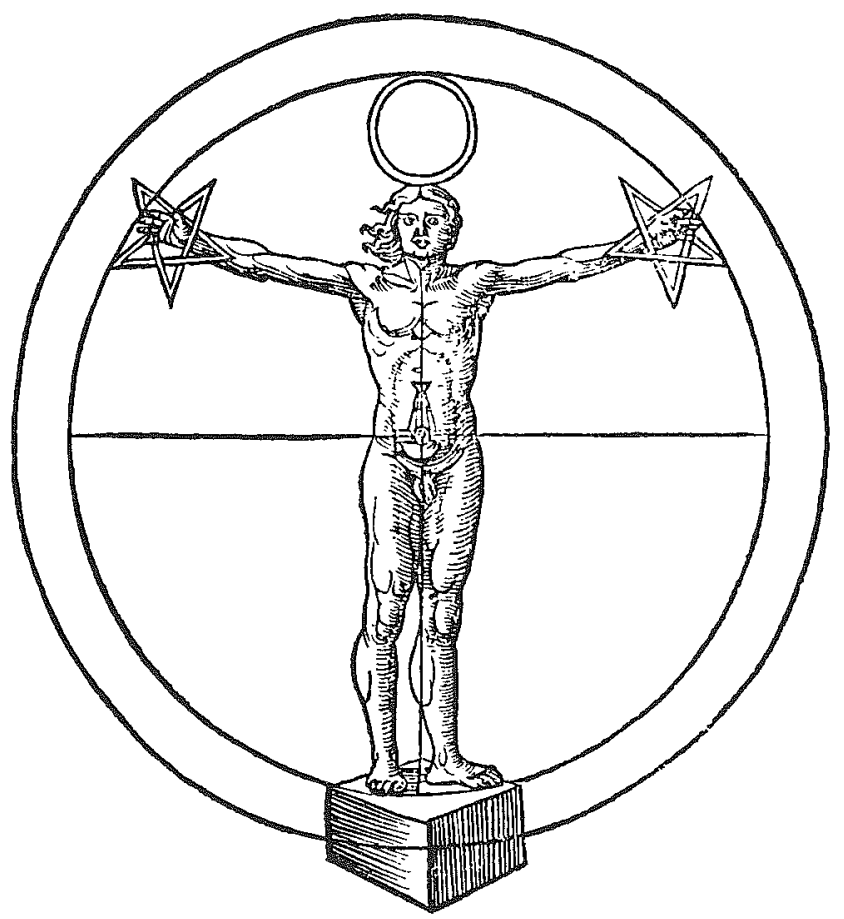

Agrippa of Nettesheim, Occulta philosophia 1. II c. Io p. I I2.

SCALA QVINARII

\begin{tabular}{|c|c|c|c|c|c|c|}
\hline 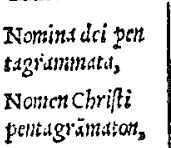 & & & 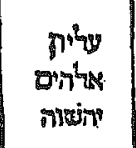 & $\begin{array}{l}\text { Elion } \\
\text { Elohim } \\
\text { Thefuh }\end{array}$ & & In archetygo. \\
\hline $\begin{array}{l}\text { Quing; fubfattic } \\
\text { inteclighblics, }\end{array}$ & 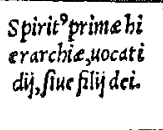 & $\begin{array}{l}\text { spiritus fecŭdes } \\
\text { bierarchia, di } \\
\text { Alintelligetie }\end{array}$ & $\begin{array}{l}\text { Spirituster } \\
\text { tiabicrarchi } \\
\text { e, uosatiange } \\
\text { li,qumittütur }\end{array}$ & $\begin{array}{l}\text { Anins cors } \\
\text { porum coe } \\
\text { leftivm. }\end{array}$ & $\begin{array}{l}\text { Heroës fiut ani } \\
\text { ma brattes }\end{array}$ & $\begin{array}{l}\text { In mundo intel } \\
\text { lettradib }\end{array}$ \\
\hline $\begin{array}{l}\text { Quindue fellle } \\
\text { erratice, domini } \\
\text { terminortim, }\end{array}$ & Sacurnus, & Iupirer & Mars & Venus & Mercurius & $\begin{array}{l}\text { In mando cose } \\
\text { ftio }\end{array}$ \\
\hline $\begin{array}{l}\text { Quinguc eners } \\
\text { sorripitibiliam. }\end{array}$ & Aqua, & Ä̈r & Ignis & Terra & Mixtum & \multirow[t]{2}{*}{$\begin{array}{l}\text { In mundo de } \\
\text { mentadi. }\end{array}$} \\
\hline $\begin{array}{l}\text { Quinquc pecirs } \\
\text { nixtorum, }\end{array}$ & Animal, & Planta & Metallü & Lapis, & Zoophytü & \\
\hline Quinquc fonfus, & Guftus, & Audicus & Vifus & Tactus & Olfactus & In miorc nsǚdo. \\
\hline $\begin{array}{l}\text { Quintque rornté } \\
\text { tacorporilitita }\end{array}$ & $\begin{array}{l}\text { Antaritudomor } \\
\text { tificatrse }\end{array}$ & $\begin{array}{l}\text { Vlulatusbonir } \\
\text { fonis. }\end{array}$ & $\begin{array}{l}\text { Tenebre ter } \\
\text { rifitles }\end{array}$ & $\begin{array}{l}\text { Ardorimex } \\
\text { tinguibilis, }\end{array}$ & Fator pentrotis. & $\begin{array}{l}\text { In munto infer } \\
\text { nuati. }\end{array}$ \\
\hline
\end{tabular}

Agrippa of Nettesheim, Occulta philosophia 1. II c. 27, p. I6I. 
doctrine persisted in numerous variations and pre-scientific conceptions. Linnæus adds a fifth element: ether, which gave him his five basic elements of nature. The old masters distinguished ether as being a rarified heavenly substance quite apart from the ordinary sub-lunar elements: fire, air, water and earth. Linnæus characterizes them with the old alchemical signs $\Delta, \Delta$, $\nabla, \nabla$ for fire, air, water, and earth, and $\bigcirc$ for the all-embracing world. ${ }^{l}$ On such a basis Linnæus could, however, hardly hope to gain any followers a generation before the great Lavoisier made his appearance in science. Linnæus' thought seems motivated by the fact that he could not resist reckoning with a substance which carried the healing powers of the remedies. The doctrine of the elements presupposed a way of thought which need not necessarily have a real counterpart in the external world.

Linnæus' conception of the five elements corresponds to the five senses, their organs and functions. These form the basis of a quinary scale in his systematics. It is not entirely surprising to find that the main points of Linnæus' quinary scale are anticipated in Agrippa of Nettesheim's Occulta philosophia. Agrippa not only presumes the existence of a "mixed" fifth element, but he also lists the five senses, the five fingers, the five erring planets etc. ${ }^{2}$

The outstretched hands on the title-page of Linnæus' Clavis correspond to the magical pentagram in the picture reproduced here from Occulta philosophia. ${ }^{3}$ Agrippa's and Linnæus' quinaries are seen in the figures.

Otto Hjelt, quite correctly I think, sums up the quinary system of Linnæus as an expression of his idea about "the perfection of the organic form". ${ }^{4}$ In accordance with this idea the plants and their special parts, which were reduced to this number, were regarded as the most developed. Consequently Linnæus tried to find this significant number in connection with diseases and their remedies. ${ }^{5}$ In this quinary system Linnæus, in the same

1 Systema naturæ, I2th ed., p. I6.

2 Agrippa, op. cit., 1. II, c. Io, pp. I I sq.; c. 2I, p. I45.

3 Op. cit., 1. II, c. 27 , pp. I60 sq. Concerning the significance of the pentad as an archetype of human measures is said: antiqui omnes, digitis olim numerabant, et digitis numeros indicabant, ex ipsisque humana corporis articulis, omnes numeros, mensuras proportionesque ac harmonias inventas fuisse, probare visi sunt. Ibidem.

4 Hjelt, op. cit., p. I27.

${ }^{5}$ Philosophia botanica, pp. 264 sqq.; Hjelt, op. cit., p. II3. 
way as Agrippa, introduced the five senses, on the supposition that their functions were correlated with the therapeutic virtues of the plant-remedies. Linnæus also regards the quinate rose as the most perfect of all flowers. The wide-spread views from bygone days concerning the magical significance of the rose, especially in connection with its rôle in alchemy and Rosicrucianism are well known. In contrast to the binaries and quinaries in the Clavis system it is rather surprising to note the absence of the hermetic triades.

In this way Linnæus becomes lost in his own system, which in the end turns into a guess-work of generalities and antitheses without any possibility of scientific verification and vindication. However, one must remember that systematizing thought in eighteenth century science, from Linnæus to Lamarck, was considered to be a discipline of natural philosophy. As empiricism it was, however, founded by John Locke together with his medical friends, Ashley and Sydenham. This trend lasted throughout the following century. But Platonism was never out of date. It confronted the new Romanticism of the post-Linnean era not only in Sweden but also on the Continent and in Great Britain. A germ can be found already in the Lockean views on the internal sense. ${ }^{1}$ Here we have one of the thin silver-threads spun throughout all i 8th century thought.

In the history of Sweden the age of Linnæus has often been named the Era of Utility. The systematics of Linnæus had a pragmatic purpose also. Its aim was a code for the order of Nature. The thoughts thus laid down in his system, were neither aimed at denying the reality of contraries nor identifying them. Linnæus did not try to distegard the antithesis between Mind and Nature, even when, at times, he tended to spiritualize matter or, contrariwise, materialize the mind. Linnæus retained the conception of God as an immediate reality. He says that "he had seen God's back". The dictum can very well hold good as a general explanation ex post. If Linnæus ever stood face to face with God it remains his own secret.

I think that such ideas can never be explained without some reference to hidden motives in Linnæus himself. During his young student years, he went through a very sensitive period when he had to make a choice between

${ }^{1}$ Lockes Essay. Edition by A. C. Fraser, Oxford r894, I, p. 123. (Book II, ch. x). 
the religious interests of his home, and a tempting, but uncertain way of life serving the knowledge of nature. It would seem probable that memories of this time remained in Linnæus' mind. Impressions from the old science, absorbed by him in youth, also reappeared throughout the later decades of his life, when feelings of despair and increasing ill-health more and more gained hold upon his soul. In the light of these facts one can understand his deeply hidden thoughts about life and the general view of the world, which he committed to paper in the Lachesis and Nemesis manuscripts. 